\title{
Re-Imagining Text - Re-Imagining Hermeneutics
}

\author{
Christopher Duncanson-Hales
}

Saint Paul University

theolog3n1@gmail.com

\begin{abstract}
With the advent of the digital age and new mediums of communication, it is becoming increasingly important for those interested in the interpretation of religious text to look beyond traditional ideas of text and textuality to find the sacred in unlikely places. Philosophical and theological hermeneutics have been invigorated by a de-regionalization of the interpretation of texts that corresponds with this journal's mandate to "cross traditional boundaries, bringing different disciplinary tools to the process of analysis and opening up a sustained dialogue between and among scholars and others who are interested in religion, textuality, media, and mediation and the contemporary world." Paul Ricoeur's phenomenological reorientation of classical hermeneutics from romanticized notions of authorial intent and psychological divinations to a serious engagement with the "science of the text" is a hermeneutical tool that opens up an important dialogue between the interpreter, the world of the text, and the contemporary world in front of the text. This article examines three significant insights that Paul Ricoeur contributes to our expanding understanding of text. First under scrutiny will be Ricoeur's de-regionalization of classic hermeneutics culminating in his understanding of Dasein (Being) as "being-in-the-world," allowing meaning to transcend the physical boundaries of the text. Next, Ricoeur's threefold under-standing of traditionality/Traditions/tradition as the "chain of interpretations" through which religious language transcends the temporal boundary of historicity will be explored. The final section will focus on Ricoeur's understanding of the productive imagination and metaphoric truth as the under-appreciated yet key insight around which Ricoeur's philosophical investigation into the metaphoric transfer from text to life revolves.
\end{abstract}


Keywords

Paul Ricoeur, Hermeneutics, Text, Interpretation, Dasein, Productive Imagination

How can language be put to such diverse uses as mathematics and myth, physics and art? It is no accident that we ask ourselves this question today. We have at our disposal a symbolic logic, an exegetical science, an anthropology, and a psychoanalysis, and perhaps for the first time, we are able to encompass in a single question the problem of the unification of human discourse. (Ricoeur 1977, 3)

\section{Introduction}

With the advent of the digital age and new mediums of communication, it is becoming increasingly important for those interested in the interpretation of religious text to look beyond traditional ideas of text and textuality to find sacred texts in unlikely places. Philosophical and theological hermeneutics have been invigorated by the de-regionalization and de-temporalization of the interpretation of texts that corresponds with this journal's mandate to "cross traditional boundaries, bringing different disciplinary tools to the process of analysis and opening up a sustained dialogue between and among scholars and others who are interested in religion, textuality, media, and mediation and the contemporary world" (Castelli n.d.). Comparative research on sacred texts is confronted by this search for a comprehensive philosophy of language that expands our gaze beyond the usual canonical suspects to include erstwhile neglected texts. Paul Ricoeur's phenomenological reorientation of classical hermeneutics from romanticized notions of authorial intent to a serious engagement with the science of the text opens up an important dialogue between the interpreter, the text, and the world in front of and behind the text. This postmodern turn to Ricoeur's hermeneutic provides a methodological bridge between explanation and understanding that enables researchers interested in the social functions of books and texts that exceed their semantic meaning to "enter seriously into a discussion with the sciences of the text, from semiology to exegesis" (Ricoeur 1981, 43). As understanding of text expands to cross-traditional exegetical and philological boundaries, a similar hermeneutical reorientation is demanded. Ricoeur's metaphoric transfer from text to life re-imagines the hermeneutics of sacred text by drawing into question the very limits of text itself.

To appreciate Ricoeur's contribution to a postmodern hermeneutic turn requires first placing Ricoeur in a postmodern frame. In his text, Overcoming Onto-Theology: Toward a Postmodern Christian Faith Merold 
Westphal presents Ricoeur's hermeneutic as a positive postmodernism that is more radical than Gadamar and Derrida, yet less radical than Kierdegaard and Nietzsche. Westphal attempts to avoid claiming Kierkegaard and Nietzsche's hermeneutics as the pinnacle beyond which a more radical hermeneutics cannot be conceived. Rather, he suggest they provide "a challenge so deep and so comprehensive that we could do worse than work on it and let it work on us for a while. The kind of hermeneutics they offer to us is anything but a mastered moment"(Westphal 2001). This argument is equally applicable to Ricoeur's hermeneutics which likewise provides a challenge so deep and comprehensive that we would be wise to take the detour of the long durée of multiple interpretations where philosophy discovers its limits in what is outside of philosophy (Kearney in Ricoeur 2006, ix).

Theologian Dan Stiver argues that one of the advantages of a postmodern turn to Ricoeur is that "he has already wrestled deeply for many years with the issues of postmodernism and has emerged with a comprehensive philosophical view that is also deeply integrated with a religious perspective" (Stiver 2001, 51). Ricoeur has developed a thoroughly postmodern view of experience, knowledge and language, each of which Stiver identifies as indicative of the postmodern paradigm shift. Citing Jerry Gills, Stiver argues that in the postmodern paradigm, experience is integrally embodied and social. Experience has "a more embodied and holistic conception of the self in the world," than the atomistic and passive view of empiricists. Meaning is not a mere add-on or ornamentation to experience but is integral to experience itself (11). The postmodern view of knowledge, Stiver argues, is epistemologically holistic (11). From this perspective "words and propositions do not stand in atomistic discontinuity from the larger stream of live or 'form of life' in which they are embedded" (11). Epistemological structure is not foundational, but construed as a web of belief as Willard Quine terms it (11). This emphasis on contextualizing meaning, which Stiver identifies as the interpretative or hermeneutic turn recognizes that all knowledge is "rooted in hermeneutical acts of judgment that cannot conclusively be proven or demonstrated" (11). Whereas experience is embodied, knowledge of this experience is always interpreted through language. The concern with the linguistic turn that characterizes most if not all postmodern perspectives is rooted in the realization that the knowledge of experience is mediated and interpreted through language (11). Perhaps in no other area does Ricoeur make a greater contribution to a postmodern perspective than in the area of language. For Ricoeur, it is language that has the potential to unify human discourse, and it is language that covers 
the alienating distanciation of postmodern critical theory. In linguistics, John van den Hengel notes, Ricoeur recognizes, "the possibility to stabilize understanding through the language used by writers and speakers. All understanding, he said, is mediated by explanation, that is, by language. Accordingly his phenomenological approach became hermeneutical" (van den Hengel 2010)

Ricoeur's student Richard Kearney further recognizes in Ricoeur's hermeneutic a profound interest in the unique capacity of language to translate not only in the literal sense, as in between French and English, but in the figurative sense, between conflicting ideas and interpretations. Ricoeur was determined, Kearney notes to "find a path between (1) the romantic hermeneutics of Schleiermacher and Gadamer and (2) the more radical hermeneutics of deconstruction (Derrida, Caputo) and Critical Theory (Habermas), Ricoeur endeavoured to chart a middle way which combined both empathy and conviction of the former and suspicion and detachment of the latter" (Ricoeur 2006, viii). This middle way, Kearney names "dialogical or diacritical hermeneutics" (ix). Diacritical hermeneutics recognizes that existence is an act of interpretation and that no interpretation is privileged. Perhaps unintentionally, where Ricoeur is the most postmodern is his challenge to the existentialist view that Being (Dasein) is accessible only through the short route of human existence. The meaning of being, Ricoeur's student Richard Kearney reminds us "is always mediated through an endless process of interpretations - cultural, religious, political, historical and scientific" (ix).

Without discounting the more radical hermeneutics of Derrida, Caputo or Habermas, this paper follows the middle path suggested by Ricoeur's long durée of multiple interpretations. The following paper examines Ricoeur's contribution to a postmodern understanding of text under the following three headings; de-regionalizing hermeneutics, de-temporalizing hermeneutics, re-imagining hermeneutics. First, Ricoeur's de-regionalization of classic hermeneutics with an emphasis on his understanding of Dasein (Being) the experience of the active, embodied subject engaged in the world is presented as an epistemologically holistic insight allowing meaning in the text to transcend the bounds of the text. This insight is illustrated by applying an ontological reading to Frantz Fanon's text Black Skin, White Masks, and Wretched of the Earth as an example of meaning that transcends the boundaries of the text.

Next, Ricoeur's three-fold understanding of traditionality/Traditions/ tradition as the chain of interpretations through which knowledge transcends the temporal boundary of life behind the text will be examined. 
This interpretative or hermeneutic turn recognizes that all knowledge is "rooted in hermeneutical acts of judgment that cannot conclusively be proven or demonstrated" (Stiver 2001, 12). This turn from modernists notions of absolute knowledge makes conflicting interpretations inevitable allowing meaning to transcend the historicity of the text.

Finally, Ricoeur's postmodern understanding of the language of the productive imagination will be examined as the underappreciated yet key insight into metaphorization as the metaphoric transfer from text to life that opens up new worlds of hope. Ricoeur recognizes that the productive imagination's capacity for letting new worlds shape our understanding is not "conveyed by images, but by the emergent meaning in our language" (Ricoeur 1981, 181). The paper concludes with an excursus that presents the New World religious tradition of Rastafari as an exemplar of the metaphorization of scripture that opens new worlds of hope and promise. Rastafari is a New World religious tradition emerging from the crucible of oppression, poverty, death and alienation, of depression era Kingston, Jamaica. Rastafari names Babylon in the oppressive forces of racial and economic oppression, while projecting hope for liberation in Zion. Theologian Jürgen Moltmann identifies Rastafari as "one of the most interesting modern forms of expression of the religion of the oppressed" (Moltmann 2000, 199). Moltmann recognizes Rastafari's unique achievements in the "development of its own underground culture, a counter-culture to the culture of the white rulers, the transformation of the dominant language into a counter-language, and the conversion of the dominant religious symbols into a subversive religion" (199). Using the erstwhile neglected sacred text, Rastafarian: The Earth's Most Strangest Man, by Rastafari elder, Mortimo Planno, ${ }^{1}$ this paper presents Rastafari's her-

1. Mortimo Planno died in 2006 following complications from thyroid cancer. The following obituary which appeared in the Guardian Newspaper provides a good insight into the importance of Planno to the genesis of the Rastafari movement. "Planno was a key figure in the rise of Rastafarianism in Jamaica. He was an elder in the Nyahbinghi mansion (or branch). of the movement when Marley and the Wailers visited his "Ras Tafari encampment" on 5th Street in Trench Town, Kingston, near Marley's own home, in the mid-1960s. There Planno, with dreadlocks and flowing white robes, called himself a "thoughtist" and acted as a spiritual guru to Rastafarians or to anyone else seeking advice. Under his influence, Trench Town had become the spiritual power point of the movement, which worshipped Ras Tafari, the original name of Ethiopian Emperor Haile Selassie I, and called for the repatriation of the descendants of black slaves from the New World to the promised land of Ethiopia. Planno was credited with bringing it recognition, rights, structure and even respectability from the 1950s. Known as Brother Kumi, he was a founding member of the Ethiopian Orthodox church in Jamaica and the driving force behind the Ras Tafari movement's first universal groundation (or general assembly) in Kingston (Davison 2006).

\section{equinoxonline}


meneutic of word, sound and power as a paradigmatic example of the power of the religious productive imagination to proclaim hope through the metaphorization of meaning in the text to life in front of the text.

\section{De-regionalizing hermeneutics}

The long durée through Ricoeur's hermeneutics begins with his investigation of nineteenth-century biblical scholar and theologian Friedrich Schleiermacher. Schleiermacher proposed a general hermeneutics that combined regional concerns for the interpretation of biblical texts (exegesis) with the interpretation of the texts of antiquity (philology) so as to "rise above not only the particular of texts, but also the particularity of the rules and recipes into which the art of understanding is dispersed" (Ricoeur 1981, 45). To arrive at a de-regionalized general hermeneutics, Schleiermacher differentiates between grammatical interpretation characterized by a critical and objective elaboration on the general rules and understanding of words and texts and a technical or romantic interpretation that appealed to the genius of the author (45).

While welcoming the desire to elevate hermeneutics beyond regional concerns, Ricoeur remains critical of Schleiermacher's failure to purge hermeneutics of the remnants of the romantic appeal to the genius of the author and the added complication "of superimposing a separate pair of opposites, divining and comparison, upon the first pair, grammatical and technical" (Ricoeur 1981, 47). The only way through this obstacle is to shift empathetic reading of the authorial intent "towards the sense and reference of the text itself" (47). Schleiermacher's biographer, Willem Dilthey, fully grasps the magnitude of the hermeneutic problem despite being bound to an epistemological framing of the debate characteristic of his time (48).

Dilthey's principle concern extends beyond the de-regionalization of hermeneutics and the coherence of texts from the past to historicism and the question of the coherence of history itself. This concern, along with the influence of the dominance of the philosophy of positivism, led Dilthey to propose an empirical methodology for human sciences that would give historical knowledge a scientific dimension akin to the methodologies associated with the natural sciences. To accomplish this, Dilthey distinguished the explanation of nature from the understanding of history as mutually exclusive modes of knowing. While satisfying the epistemological longings of hermeneutics, Dilthey concedes to the natural sciences naturalistic explanations in favour of the more psychological intuition of understanding. Following the neo-Kantian currents of his time, Dilthey 
saw the individual as the source and summit of the human sciences, one who, although a social being, is conceived in the singular. Such a dichotomy lays the foundation of human sciences squarely at the feet "of the individual acting in society and in history" (Ricoeur 1981, 49).

Ricoeur concludes that the fundamental presupposition that dominates Dilthey's work is a "variety of the theory of knowledge and that the debate between explanation and understanding can be contained within the limits of the Methodenstreit [methodological dispute] dear to the neo-Kantians" (Ricoeur 1981, 53). Ricoeur shifts the ontological ground by digging "beneath the epistemological enterprise itself to uncover it's properly ontological conditions" (53). The de-regionalization of hermeneutics, Ricoeur argues, can only take us so far towards the ultimate goal of a fundamental hermeneutics. To reach this goal requires a second movement towards radicalization where the epistemological concerns of hermeneutics as a science are subordinate to the underlying ontological shift in understanding from a mode of knowing to a mode of being. The subordination of epistemology by ontology displaces the opposition between understanding and explanation from a place within epistemology to an opposition between epistemology and ontology as a whole (59). This displacement bogs hermeneutics down in a foundational ontology, where it is unable to make the return journey to the proper epistemological status of the human sciences. This leads Ricoeur to pose the question, "how can a question of critique in general be accounted for within the framework of a fundamental hermeneutics?" (59).

The question of critique may seem like a non sequitur but it is important because on the epistemological plane, the problem of the indeterminacy of the subject and object relation remains. This indeterminacy emerges from an endless hermeneutical circle where "the subject enters into knowledge of the object; and in turn, the former is determined, in its most subjective character, by the hold which the object has upon it even before the subject comes to know the object" (Ricoeur 1981, 59). Ricoeur recognizes the need for further elaboration without succumbing to the indeterminacy of alienating distanciation, which Gadamer identifies as the "ontological supposition that sustains the objective conduct of the human sciences" (60).

Ricoeur encounters Gadamer at the intersection of phenomenology and hermeneutics, "where hermeneutics that has become ontological meets ontology that has become hermeneutical" (Stiver 2001, 40). In Truth and Method, Gadamer synthesizes the first two movements of hermeneutics (regional to general and epistemological to ontological) which launches 
Ricoeur's own project to put hermeneutics on the ascending plane to an epistemological foundation. Gadamer's central concern is to defend the validity of truth in the so-called soft disciplines (art, humanities, histories, etc.) against the scientific conception of truth. Beginning with an analysis of the aesthetic sphere, Gadamer challenges Kant's dismissal of taste as inconsequential to pure reason, arguing that this dismissal lays the foundation for the radical subjectivization of the aesthetic found in Kant's Critique of Aesthetic Judgment (Gadamer 2004, 45). Radical subjectivization engenders the theoretical stance of the human sciences usurping the primordial sense of belonging (Ricoeur 1981, 60). Gadamer argues that this stance demands "that one "deal with something that is not immediate, something that is alien, with something that belongs to memory and to thought.' Theoretical Bildung leads beyond what man knows and experiences immediately. It consists in learning to affirm what is different from oneself and to find universal viewpoints from which one can grasp the thing, 'the objective thing in its freedom,' without selfish interest" (Gadamer, 2004, xii). Ricoeur identifies the core experience of "the distancing from the immediacy of desire, of personal need and private interest, and the exacting demand of a universal" as alienating distanciation (Gadamer 2004, xii; Ricoeur 1981, 59). Hermeneutics' claim to universality rises from "the scandal constituted, at the level of modern consciousness, by the sort of alienating distanciation (Verfremdung) which seems to him to be the presuppositions of the human sciences" (Ricoeur 1981, 60). Alienation "is much more than a feeling or a mood;" Ricoeur argues, "it is the ontological presupposition which sustains the objective conduct of the human sciences. The methodology of these sciences ineluctably implies, in Gadamer's eyes, a distancing, which in turn expresses the destruction of the primordial relation of belonging." (60).

The debate between belonging and alienation as expressed in the traditional spheres of knowledge (the aesthetic sphere, the historic sphere, and the sphere of language) leads Gadamer to seek a legitimate experience of truth beyond the narrow, empirical, and quantifiable bounds of the natural sciences. The truth in art, for instance, "becomes a history of worldviewsi.e., a history of truth, as it is manifested in the mirror of art. It is also a fundamental recognition of the task that I formulated thus: to legitimate the knowledge of truth that occurs in the experience of art itself" (Gadamer 2004, 84). This experience of art, he argues, concerns truths beyond the application of technique or the skill of the artist; it corresponds to truths in the experience of history that go beyond the acumen of the historical investigator. The correspondence between truths, Gadamer maintains is 
"Fundamentally, the experience of historical tradition reaches far beyond those aspects of it that can be investigated objectively. It is true or untrue not only in the sense in which historical criticism decides, but always mediates truth in which one must try to share" (Gadamer 2004, xxii). Truth is mediated by the historical which precludes the objectification of history because history is itself a part of the historical phenomenon (Ricoeur 1981, 61). "It is the consciousness of being exposed to history and to its action, in such a way that this action upon us cannot be objectified, because it is part of the historical phenomenon itself' (61). Thus, the historical observers participate in that which they observe.

A refinement of the question of critique returns us to Ricoeur's personal hermeneutical dilemma. Rather than, "how can a question of critique in general be accounted for within the framework of a fundamental hermeneutics," Ricoeur asks, "how is it possible to introduce a critical instance into a consciousness of belonging, which is expressly defined by the rejection of distanciation?" This is only possible, argues Ricoeur, if historical consciousness not only seeks to repudiate alienating distanciation, but also assumes it. Alternatively, in repudiating alienating distanciation, the consciousness of historical efficacy takes on an element of distance. The history of effects, Ricoeur argues, "is precisely what occurs under the condition of historical distance. It is the nearness of the remote; or to say the same thing in other words, it is the efficacy at a distance. There is thus a paradox of otherness, a tension between proximity and distance, which is essential to historical consciousness" (Ricoeur 1981, 61). It is here where Ricoeur joins the postmodern concern with alterity engendered in transition from the alterity of self to the alterity of text. This transfer, Ricoeur argues,

redirects hermeneutics to ethics, more precisely to an ethics which assigns a central place to the phenomenon of alterity. I allow myself to point out that this is a place for diverse philosophies of alterity: asymmetric for Levinas, reciprocal for Hegel. Here there is also a place for diverse figures of alterity: corporeality, the encounter of the Other, the search for interiorized moral consciousness. Here one may also find the diverse figures of others, others qua face-to-face encounter; others such as the "each one" of the relations of justice. I accept in good will that these figures of alterity, and of the other, may come to be summarized and to culminate in the moment of alterity in which the other is the poor. It is here that the philosophy and theology liberation search for and find themselves.

(Dussel and Mendieta 1999, 212)

What Ricoeur adds to this place of diverse philosophies of alterity is the recognition that the deconstruction of reified institutions of oppression is only the first part of the journey. The journey must continue so as to 
"connect past and future in an exchange between memory and expectation" (Kearney 2004b, 152).

The paradox of otherness in the tension between nearness and remoteness of the past and future is overcome through the fusion of horizons and the universality of language. The completion of the return journey to an epistemological foundation for hermeneutics is the threshold for Ricoeur's semantic innovation. This fusion of horizons, Ricoeur maintains, is an extension of the tension between alienating distanciation and the primordial sense of belonging. Horizons are the dynamic situation of being-in-the-world. The fusion of horizons, whether across time, cultures, or texts, occurs through the communication between "differently situated consciousness, that is, the intersection of their views on the distant and the open" (Ricoeur 1981, 62). Horizons are neither open nor closed. While excluding the notion of unique or total knowledge, the fusion of horizons encompasses the paradox of alienating distanciation (far) and primordial sense of belonging (near) "The concept implies a tension between what is one's own and what is alien, between the near and the far; and hence the play of difference is included in the process of convergence" (62).

Mediating between the near and far is the universal linguistic characteristic of human experience. Human experience, Ricoeur argues, "Belonging to a tradition or traditions passes through the interpretation of the signs, works, and texts in which cultural heritages are inscribed and offer themselves to be deciphered" (Ricoeur 1981,62). Language mediates belonging as "interlocutors fade away in face of the things said." (62). The distanciation of the things said finds its fullest expression in the matter of the text, which belongs to neither the author nor the reader. Language as expressed in text mediates the near and far, the familiar, and the alien. The most precise indication for a less negative interpretation of alienating distanciation" (62). Text, Ricouer argues, bridges this gap "through the ontological encounter between tradition and imagination." Ricoeur develops this practical understanding of being-in-the-world by digging "beneath the epistemological enterprise itself to uncover its properly ontological conditions" (53).

Ricoeur arrives at this properly ontological condition through two related movements. The first is the two-fold inversion suggested by Heidegger in Time and Being, in which the first inversion subsumes the epistemological aspirations of the human sciences with a concern for the primordial ontological condition of understanding. The second inversion de-psychologizes hermeneutics by reorienting Dasein (Being) from the existentialist's relation of being-with to an ontological situation of 
being-in-the-world. The first movement of two-fold inversion of the ontological condition of understanding is followed by the second movement of a return to epistemological claims through Gadamer's synthesis of the hermeneutics of Schleiermacher and Dilthey.

Heidegger's two-fold inversion is of interest to Ricoeur because it asks "the question of the meaning of being" (Ricoeur 1981, 54). Dasein is not an existential state, but rather, an ontological state of being-there that we are. Being is irreducible and ontologically hermeneutical and precedes any question of subject/object split (Stiver 2001, 38). Dasein, Ricoeur argues, "is not a subject for which there is an object, but is rather a being within a being. Dasein designates a place where the question of being arises, the place of manifestation; the centrality of Dasein is simply that of a being that understands being" (Ricoeur 1981, 54). What is at stake, argues Ricoeur, "is the explication of those beings with regard to their basic state of being. This explication will add nothing to the methodology of the human sciences; rather, it will dig beneath this methodology in order to lay bare its foundations" (55).

According to Ricoeur, this first inversion from epistemology to ontology is followed by a second inversion where the question of beingin-the-world is a necessary precondition to the existential question of being-with-another. If Dasein, as Ricoeur argues, "designates a place where the question of being arises, the place of manifestation," then understanding is not found in relations between beings, à la Dilthey, but through being-in-the-world. This variant reading of Dasein, Ricoeur argues, is "completely misunderstood" by existentialist interpretations of Heidegger. The refined existentialist psychology of being-towards-death or other uncommon states of mind does not comprehend or sufficiently recognize "that these analyses are part of a meditation on the worldliness of the world, and that they seek essentially to shatter the pretension of the knowing subject to set itself up as the measure of objectivity" (Ricoeur 1981, 56). Ricoeur questions the authenticity of this pretension, noting that "if there is a region of being where inauthenticity reigns, it is indeed in the relation of each person with every other; hence, the chapter on being-with is a debate with the 'one,' as the centre and privileged place of dissimulation" (55). The "being-with another who would duplicate our subjectivity" and the "capacity to transpose oneself into the mental life of others" runs aground against the unknown of the other, including myself.

For Ricoeur, understanding arises out of the power to be, not in a linguistic or literary form, but rather, as an orientation to a situation. The first function of understanding is "apprehending a possibility of being... 
To understand a text, we shall say, is not to find a lifeless sense which is contained therein, but to unfold the possibility of being indicated by the text" (Ricoeur 1981, 51). Understanding, then, is a projection emerging from the situation of being-in-the-world, or as Ricoeur puts it, "a projection within a prior being-thrown" (51). Interpretation or the exegesis of a text only emerges as a third position following the exegeses of things, forming the triad situation/understanding/interpretation. This third position adds nothing new to a text but allows what is already there to emerge. Quoting Heidegger, Ricoeur argues that interpretation manifests meaning, "as a development of understanding which 'does not transform it into something else, but makes it become itself" (57).

Being-in-the-world precedes understanding and anchors the whole linguistic system, "including books and texts..., which is not primordially a phenomenon of articulation in discourse" (Ricoeur 1981, 55). Being-in-theworld requires that we first situate ourselves and feel for ourselves before orienting ourselves to understanding. Rather than exploiting fear, anguish, and alienation in the one who exists, Ricoeur recasts these feelings as revelatory experiences that disclose our link to "a reality more fundamental than the subject-object relation. In knowledge we posit objects in front of us; but our feelings of the situation precede this vis-à-vis by placing us in the world" (56). Ricoeur's objection to an existentialist reading of Dasein echoes similar objections raised by the black intellectual, Frantz Fanon.

In Black Skins, White Masks, Fanon presents the compelling argument that ontological investigations in situations of oppression are derailed by the situation of, in the case of Fanon, being black in a world defined by white. Much of the debate over otherness and the relation between subject and object, Fanon argues, ignores the construction of race and oppression:

As long as the black man remains on his home territory, except for petty internal quarrels, he will not have to experience his being for others. There is in fact a "being for other" as described by Hegel but any ontology is made impossible, in colonized and acculturized society. Apparently, those who have written on the subject have not taken this sufficiently into consideration. In the weltanschauung of colonized people, there is an impurity, or a flaw that prohibits any ontological explanation. Perhaps it could be argued that this is true for any individual but such an argument would be concealing the basic problem. Ontology does not allow us to understand the being of the black man, since it ignores the lived experience. For not only must the black man be black; he must be black in relation to the white man. (Fanon 1967, 89-90) 
Dasein as being-in-the-world does not ignore the lived experience of the oppressed or the oppressor; rather it gives priority to, without succumbing to, the alienation inherent in the situation of being-in-the-world. The implication of this shift from existential to ontological reading is illustrated in Fanon's, The Wretched of the Earth: When read existentially, Dasein appears as a hopeless situation of being in a relation of violence. For instance, in the chapter "Concerning Violence," Fanon writes, "The native who decides to put the program into practice, and to become its moving force, is ready for violence at all times. From birth it is clear to him that this narrow world, strewn with prohibitions, can only be called in question by absolute violence" (Fanon 1965, 37). Read existentially, how could this be anything other than a violent call to arms? When read ontologically, however, the avocation of violence is transformed into a recognition of the violent world of colonization and decolonization in which the wretched of the earth are thrown.

The historically contingent process of colonization and decolonization situates both the settler and the native's being-in-the-world "divided into compartments, this world cut in two is inhabited by two different species." There is no being-in-relation when, as Fanon notes, "it is evident that what parcels out the world is to begin with the fact of belonging to or not belonging to a given race, a given species" (Fanon 1965, 40). The return journey from this alienation, Fanon concludes "consists of reintroducing mankind into the world, the whole of mankind...carried out with the indispensable help of the European peoples, who themselves must realize that in the past they have joined the ranks of our common masters where colonial questions are concerned" (106).

Cynthia Nielsen arrives at a similar conclusion in her article, "Resistance Through Re-narration: Fanon on De-constructing Racialized Subjectivities," concluding that:

Fanon sought to transform and re-form a truly universal humanism appreciative of all cultures, embracing the "reciprocal relativism" of each for the purpose of mutual enrichment and genuine fraternité (Fanon 1969, 44)-humanism as a symphony composed of many cultural voices, each of which has a distinctive part contributing to the beauty of the whole (ongoing) composition. Fanon's historically sensitive humanism neither turns a deaf ear to the cries of lives lost to the colonial project, nor chases frantically after "European achievements," "increased productivity," or a nostalgic return to nature (Fanon 2004, 237, 238). Fanon's quest began and concluded with a call to "reexamine the question of man," "to invent a man in full, something which Europe has been incapable of achieving."

(Nielsen 2011, 385) 
Reintroducing humanity into the world, the whole of humanity is recognition of "a reality more fundamental than the subject-object relation. In knowledge we posit objects in front of us; but our feelings of the situation precedes this vis-à-vis by placing us in the world" (Ricoeur 1981, 56). Positing objects in front of us and placing us in the world is a temporal succession that is ultimately imagined. Fanon re-orients both the native and the settler to the already violent situation of colonization and decolonization beyond which he imagines a utopic future of national consciousness and culture liberated from being-in-the-world of colonization and decolonization.

This projected reality, while more fundamental than the subject-object, does not ignore the situation of being-thrown-into a world of oppression. While reanimating a better future, The Wretched of the Earth fully acknowledges lost opportunities and betrayed possibilities, as evidenced by the chapters "The Pitfalls of National Conciousness," and the even more telling chapter, "Colonial War and Mental Disorder." An ontological reading of The Wretched of the Earth illustrates the exchange between the space of being-in-the-world of alienating distanciation and the horizon of hope. Texts of this form, Ricoeur maintains, are:

The most notable expression that the past experience of our predecessors comes to us in the form of a received inheritance, of transmitted traditions. It is, in another time and now, under the textual form that the great changes between the past of the tradition and the future of our most alive hopes, according to which our Utopias require that they be considered, are founded. (Ricoeur in Dussel and Mendieta 1999, 211)

In anticipation of a more thorough discussion of utopia below, it will be helpful to clarify Ricoeur's understanding of utopia. Ricoeur notes in an interview with Richard Kearney, published in Debates in Continental Philosophy, that:

The epistemic status of Utopia is very complex. I tried to explore this issue in my book Lectures on Ideology and Utopia. There I argued that ideology usually reasserts the historical field of past experience in a gesture of reassurance. Utopia, by contrast, attempts a kind of excursion out of time, a radical break into the future. There is a moment of madness in utopia

2. "Colonial War and Mental Disorders" is particularly interesting. Using clinical studies, Fanon presents "the many, sometimes ineffaceable wound that the colonialist onslaught has inflicted on our people."(Fanon, 249). Interestingly, the studies which follow includes a number of European police involved in the suppression of the Front de Libération Nationale (FLN) and the Armée de Libération Nationale (ALN). Both are included, the common denominator being the affect of violence and torture on both the patriot and the colonial police. 
which is irreducible to mere repetition. Utopia claims to be imagination of the new, of a pure beginning. But the opposition is not so simple. No historical period ever exhausted its own dreams. What happened in the past is only a partial realization of what had been projected. We may say this of the Greek city which failed and of the Roman Empire which was rescued by the Catholic Church as the Holy Roman Empire, before it collapsed again. The promise of an historical event is always more than what was actually realized. There is more in the past than what happened. And so we have to find the future of the past, the unfulfilled potential of the past. (Kearney 2004a)

This understanding of utopia as a kind of excursion out of time, a radical break into the future is similar to that proposed by Elizabeth Castelli in her text, "The Ekklesia of Women and/as Utopian Space: Locating the Work of Elisabeth Schüssler Fiorenza in Feminist Utopian Thought." In this context, Castelli defines utopia as "the literary genre that imagines an alternative social/political reality. It can also refer to the alternative social formation generated out of such texts or individual/collective imaginings. The adjective "utopian" refers in this essay broadly to texts, institutions, and worldviews that critique the historical or contemporary situation and promote an alternative vision of social and individual existence-generally, a vision committed to more egalitarian and just structures and stances" (Castelli 2004, 38). For Ricoeur, utopia is the Epochě of/from reality out of which and into which the productive imagination projects hope, to imagine an unfulfilled past. It is this hermeneutic of imagining that "rises above not only the particularity of texts, but also the particularity of the rules and recipes into which the art of understanding is dispersed" (Ricoeur 1981, 45). This utopic nowhere is not a duplicate of an original reality, but rather, expands understanding of reality. George H. Taylor, quoting Ricoeur, writes that utopia is "the possibility of nowhere in relation to social condition. At its best, the utopia is not only an escape from reality, but it points to a new kind of reality" (Taylor 2006, 96).

Alienating distanciation from the text may be overcome, but the resulting conflict of interpretations requires that meaning transcend the bounds of the text and the historicity of the text as it has been interpreted over time. The de-temporalization of hermeneutics does not ignore this conflict of interpretations, but rather approaches hermeneutics as a chain of interpretations. Ricoeur's understanding of the three-fold movement of tradition is the vehicle through which meaning transcends the alienating distanciation of the historicity of the text. 


\section{De-temporalizing hermeneutics}

The following section considers tradition in anticipation of the treatment of imagination. While Ricoeur's philosophical project is the hermeneutic of imagination, tradition is the cornerstone that anchors this project in historical contingency. Ricoeur's conception of historical contingency is grounded in a two-fold understanding of historicity. Since "semantic regulation proceeds from the excess of potential meaning over its use and function inside the given synchronic systems,...the hidden time of symbols can carry the two-fold historicity" (Ricoeur 1974a, 45). This two-fold historicity, Ricoeur continues, consists "of tradition, which transmits and sediments the interpretation, and of interpretation, which maintains and renews the tradition" (Ricoeur 1981, 49). Tradition rejects any claim to a totalizing mediation of history in the form of absolute knowledge. Along with the rejection of any form of absolute knowledge, Ricoeur rejects the pretension that the self-understanding of historical consciousness is unaffected by events. On the contrary, Ricoeur argues, "To admit that the selfunderstanding of the historical consciousness can be so affected by events that, to repeat, we cannot say whether we produced them or they simply happened is to admit the finitude of the philosophical act that makes up the self-understanding of the historical consciousness" (Ricoeur 1984, 1: 206).

In contrast to finitude, Ricoeur proposes an "open-ended, incomplete, imperfect mediation, namely, the network of interweaving perspectives of the expectation of the future, the reception of the past, and the experience of the present with no Aufhebung into a totality where reason in history and reality would coincide" (Ricoeur 1988, 207). Rather than viewing tradition as a fait accompli, Ricoeur reconfigures tradition as "an ongoing dialectic between (a). our being-affected-by-the-past and (b). our imaginative projection of history-yet-to-be-made (la visée de l'histoire à faire)" (Kearney 2004b, 60).

In the case of the former, history is not something that happened back then, but is something back then that affects us now. In the case of the latter, our expectation of the future is the world we hope for, a projected utopia. For this utopia to become real, our expectations must be realistic and grounded in the field of experience, including our experience of the past and our experience of the present. Intermediary projects in the realm of social action bring our hope for a better world closer to reality. The challenge is to rediscover tradition not as something dead and consigned forever to the past, but rather as a living tradition, "an ongoing history, thereby re-animating its still unaccomplished potentialities" 
(Kearney 2004b, 61). Ricoeur proposes a critical reinterpretation of tradition that respects historical continuity and discontinuity, mediating between our being-affected-by-the-past and our imaginative projection of history-yet-to-be-made.

Ricoeur's poetic hermeneutic of the productive imagination reinterprets "cultural heritages received from the past and the interest in the futuristic projections of a liberated humanity" (Ricoeur 1981, 100), by distinguishing between three facets of historical memory: traditionality, traditions, and Tradition. The first facet of historical memory traditionality is the dialectic between sedimentation and innovation. Traditionality is not an inert deposit, but it "signifies that the temporal distance separating us from the past is not a dead interval but a transmission that is generative of meaning. ...tradition is an operation that can only make sense dialectically through the exchange between the interpreted past and the interpreting present" (Ricoeur 1988, 221). These memories are not interior perceptions of an inaccessible imagination, but are bound images of the productive imagination. Traditionality is a formal conceptualization of time and space between then and now, a space crossed by traditions.

Whereas traditionality is conceived as a formal concept and is therefore somewhat abstract, traditions are the material content of traditionality (Kearney 2004b, 63). Traditions mark the transition between form and content that is necessitated by acts of interpretation. The essential characteristic of this transition is the situation of being heirs to the past: "The notion of tradition, taken in the sense of traditions, signifies that we are never in a position of being absolute innovators, but rather are always first of all in the situation of being heirs" (Ricoeur 1988, 221). This situation of being heirs is a result of "the language-like [langagière] structure of communication in general and of the transmission of past contents in particular" (221). The communication of traditions, which is essentially linguistic, includes not only the "natural languages," "but things already said, understood, and received" (220). In this sense, traditions form a symbiotic relation with communication as far as the things already said, understood, and received are communicated "along the chains of interpretation and reinterpretation" (221). Ricoeur maintains, "to refer to those things said in the past and transmitted to us through a chain of interpretations and reinterpretations, we must add a material dialectic of contents to the formal dialectic of temporal distance [that is, traditionality]. The past puts us into question before we put it into question. In this struggle for the recognition of meaning, the text and the reader are each in their turn familiarized and defamiliarized (221). 
Ricoeur's three-fold analysis of Traditionality/traditions/Tradition saves the question of truth for the last category-Tradition. Tradition is the material dialectic that recognizes the truth of the past through the chain of interpretations and reinterpretations. The interpretation and reinterpretation of traditions by Tradition is not exclusively subjective. There is a truth that traditions propose and that Tradition seeks to understand. This truth is not consigned to the past but is revealed in dialogue with the present. The present listens to the truth claims of memory before passing judgement on these claims. "We are spoken to," Kearney notes, "before we speak; we are posited in tradition before we posit tradition; we are situated before we are free to criticize the situation...the Enlightenment claim to neutral, ahistorical judgement residing above all prejudice is itself a prejudice" (Kearney 2004b, 64). Every proposal of meaning is a truth claim subject to judgement; however, this judgement is prejudiced not in the Enlightenment's limited and limiting understanding of prejudice, but as a rehabilitated prejudice that is turned against itself. "This truth claim," Ricoeur argues, "does not proceed from us, but rather rejoins us as a voice coming from the past, [and] gets enunciated as the self-presentation of the 'things themselves.' The prejudged is thus a structure of the pre-understanding outside of which the "thing itself' cannot make itself heard. It is in this sense that his rehabilitation of prejudice takes on the Enlightenment's prejudice against prejudice" (Ricoeur 1988, 222).

Tradition, argues Ricoeur, carries us along as it situates us in a chain of interpretation and reinterpretation. This chain is not infallible. Being situated in a Tradition means we accord Tradition the benefit of a presumption of truth. This presumption is not in the absolute sense, but in the sense that we presume the truth of Tradition until a better argument prevails (Kearney 2004b, 65). Since tradition(s) is/are not the immutable past and the presumption of truth is not absolute, it is then important to be able to distinguish true interpretation from false interpretation.

A critical hermeneutics of Tradition rejects the pretence that the past can be reproduced and experienced today, and is aware of the temporal distanciation between then and now. The question that remains is the legitimacy of interpretation. Who has the authority to judge Tradition? Rather than looking to an ideal of undistorted communication that runs the risk of presenting an indefinite and ultimately unrealizable future (à la Habermas), or a monological transcendental self-reflection devoid of a conversation partner (Husserl), Ricoeur proposes a historical dialectic between a determined horizon of expectancy and a specific space of expe- 
rience to validate interpretation. The material content of traditions is the truth as interpreted while "tradition is an operation that can only make sense dialectically through the exchange between the interpreted past and the interpreting present" (Ricoeur 1988, 221). This historical dialectic of truth, Kearney summarizes, is encountered through "the transcendence of the idea of truth, which is a dialogical idea from the onset, must be perceived as already at work in the practice of communication. Thus reinstated in our horizon of expectancy, the dialogical idea is compelled to rejoin the buried anticipations of tradition itself" (Kearney 2004b, 65).

Hermeneutics brings near what is far, and in making sense of odd predications, imagines the truth. "The productive imagination," Ricoeur argues, transcends the temporal and spatial boundaries of meaning, which is the core of creative thought, "whether that creativity takes the form of social, epistemological, or poetic imagination" (Taylor 2006, 98). While never systematized in his published works, Ricoeur presents the role of the productive imagination in the historical dialectic of tradition, contending that "the possibility of historical experience in general resides in our capacity to remain exposed to the effects of history, to borrow Gadamer's category of Wirkungsgeschichte. However, we continue to be affected by the effects of history only to the extent to which we are capable of broadening our capacity to be so affected. Imagination is the secret of this competence" (Ricoeur 1991, 181). ${ }^{3}$ The imagination gives us the capacity to enter the world that the text opens to us. The imagination enables us to be receptive to the effects of history, to receive traditions. Ricoeur's three-fold investigation of traditionality/traditions/Tradition illustrates the reflective power of a hermeneutic of imagination, while his hermeneutic of the productive imagination goes further and reinterprets "cultural heritages received from the past and the interest in the futuristic projections of a liberated humanity" (100). The imagination envisions a world different from the one we experience.

3. Ricoeur's Imagination Lectures, delivered at the University of Chicago in the fall of 1975 , provide the most complete presentation of the centrality of the productive imagination to Ricoeur's thought. George H. Taylor, who transcribed these texts for a forthcoming volume, argues that "these lectures came at a critical cusp in Ricoeur's career...At this central juncture, Ricoeur is crystallizing his thoughts on poetics (and so fulfilling in a recast way the third part of his Philosophy of Will). Imagination lies at the heart of his thinking at this time" (Taylor 2006, 93). I am indebted to Dr. Taylor who provided me with the unpublished transcripts of Ricoeur's Imagination Lectures. Each chapter of the transcription's pagination restarts with the numeral $<1>$. For the sake of clarity, page references to the transcribed lectures are provided with the year of the transcription and chapter number followed by the page number. Thus page 6 of chapter 15 appears as (Ricoeur 2009, 15:6). 


\section{Re-imagining hermeneutics}

The capacity to imagine an alternative world requires the movement from the reproductive to the productive imagination. This movement shifts the focus of philosophical reflection from the dominant approach of a reproductive imagination rooted in image to Ricoeur's alternative productive imagination rooted in the framework of the semantic and linguistic orientation developed in his theory of metaphor.

Ricoeur's reflection on the productive imagination begins with the question, "What is it to have an image?" He notes that a philosophical investigation into this question is immediately confronted by "a series of obstacles, paradoxes, and stumbling blocks that perhaps explain the relative eclipse of the problem of imagination in contemporary philosophy" (Ricoeur 1991, 168). Chief among these obstacles is the empiricist theory of knowledge that privileges reproductive imagination's focus on the image. Ricoeur's main concern is that the term image is generally understood as a mental, private, and unobservable entity (169). Ricoeur rejects the traditional reproductive model of image as "first and foremost a 'scene' unfolding in some mental 'theatre' before the gaze of an internal 'spectator"' relegating image to the inaccessible realm of the interior mental representation of perception, which is inaccessible to outside observation. Beginning by quoting Ricoeur, Taylor notes, "Imagination is not at all an alternative to perception [as it is in Hume] but [is] an ingredient of perception. It's encapsulated within the framework of perception.' Elsewhere in these materials Ricoeur argues that '[w] can no longer oppose...imagining to seeing if seeing is itself a way of imagining, interpreting, or thinking"' (Ricoeur 2006, 94). The false opposition between imagination and perception is the blind alley down which philosophical reflections on imagination have stumbled.

In his 1975 Imagination Lectures delivered at the University of Chicago and transcribed in 2009 by George H. Taylor, Ricoeur identifies three inadequacies in philosophical theories of the reproductive imagination: 1) the reliance on an already existing referent; 2) the marginalization of the appearance of reality; and 3) the isolation of the image from a broader framework. (Ricoeur 2009, 15: 1-8). Theories of the reproductive imagination understand the image as referring to something that is absent, and is therefore always a derivative and never original. This model of the original as a copy that is, at best, a derivative of reality and at worst, marginal, or an escape from reality produces nothingness (Taylor 2006, 96). The nothingness of absence, Ricoeur reasons, annihilates the object imagined, replacing it with a quasi-object or a pretend object. In either case, the imagined is unreal, "the negativity of nothingness, alongside the 
non-existence of the fictional object" (Ricoeur 2009, 15: 2). Nothingness is a fundamental trait of the object. It is the inaccuracy of the construction of the concept of nothingness that limits theories of the imagination to the reproductive. Ricoeur's rejection of this nihilistic understanding of nothing in favour of a formation of nothing as the utopic Epochě of/ from reality liberates the productive imagination from the referent of the image or the original, giving the productive imagination the capacity to imagine something truly new.

Philosophical theories of the reproductive imagination are limited by the fascination with replicating or reproducing reality, which turns the imagination in on itself and away from a more productive relation to reality that Ricoeur provisionally terms the "productive referent." The productive referent provides new insights into reality by creating its own original. "The image," Ricoeur argues, "Already has a reference that is not its own reference but the reference of the perception, the possible perception of the thing, what we call the original of the copy, the original of the photograph, even the original of a painting. But we shall see that in painting we have more than a copy; we have a certain creation of its own original" (Ricoeur 2009, 15: 3). The productive imagination does not create without a referent so much as, to use Ricoeur's language, the referent of the productive imagination is produced by the imagination.

Ricoeur contrasts the productive referent's relation to image without an original against that of the reproductive referent's relation to an image that already has an original. Such an image can only try to approximate that which it reproduces, which is not the original object's reference, but a reference of the possible perception of the object (Ricoeur 2009, 15: 4). Ricoeur uses the difference between a painting and a photograph to illustrate the difference. By exposing film to the light reflected by the subject, a camera produces a photograph that is a reflection of the light of the original. The original subject exists only in the moment of the opening and closing of the camera's shutter. The photo is the original of the photograph. Ricoeur explains,

When I look at a photograph, I no longer posit the nonexistence of the photographic subject's presence. I neutralize this positing in order to direct myself to the absent object, which exists elsewhere. To look at a picture with a kind of mock observation preserves both the likeness and the nothingness. But this interplay of likeness and nothingness has no influence on the object as such. It is only for reflection that the appearance raises a problem of its own, that this appearance is marginal in relation to the real object. (Ricoeur 2009, 15: 4) 
Ricoeur contrasts marginalization of reality by the reproductive imagination with the augmentation of reality by the productive imagination. A painting, for instance, is not only a copy of an original; it is also a creation of its own origin. Within the work of a painting, framed, is the creation of a reality that is more than the image reproduced. Ricoeur notes that early photography developed for the purpose of preserving fleeting memory and fleeting images of reality. As such, it was reproductive. Painting had to distance itself from photography because it could no longer re-present reality as photography could. Impressionism emerged to overcome photography by "creating a new alphabet of colors capable of capturing the transient and the fleeting with the magic of hidden correspondences. Once more, reality was remade with an emphasis on atmospheric values and light appearances" (Ricoeur 2009, 17: 13).

Merleau-Ponty makes a similar observation in his essay, Cézanne's Doubt, arguing that the result of impressionists attempt to "capture, in the painting, the very way in which objects strike our eyes and attack our senses... was that the canvas-which no longer corresponded point by point to nature [and] restored a general truth of the impression through the action of the separate parts upon one another" (Merleau-Ponty 2007, 71). The emphasis on atmospheric values and light appearances, Merleau-Ponty argues, resulted in the submersion of the object being depicted, "causing it to lose its proper weight" (63). Cézanne's responds to this submersion of the object with "The use of warm colors and black that shows Cézanne wants to represent the object, to find it again behind the atmosphere ... with a modulation of colors which stays close to the object's form and to the light it receives" (72).

From Ricoeur's perspective, the object being depicted is in the frame of the painting, on the canvas, not the apple on the table that has long since rotted away. Merleau-Ponty's perception of the submersion of the proper weight of the object being depicted is suggestive of the reproductive imagination's marginalization of reality. That said, Cezanne's attempt to restore the weight of the object being depicted, despite the apparent intent to replicate reality, illustrates "a reference that is not its own reference but the reference of the perception, the possible perception of the thing" (Ricoeur 2009, 15:2). Cézanne, Merleau-Ponty notes:

Remarked that "as soon as you paint you draw," by which he meant that neither in the world as we perceive it nor in the picture which is an expression of that world can we distinguish between, on the one hand, the outline or shape of the object and, on the other hand the point where colours end or fade...Cézanne strives to give birth to the outline and shape of 
objects in the same way that nature does when we look at them: through the arrangement of colours. This is why, when he paints an apple and renders its coloured texture with unfailing patience, it ends up swelling and bursting free from the confines of the well-behaved draughtsmanship.

(Merleau-Ponty 2007, 51-52).

In "Practical Theology and the Emergence of the New Self," John van den Hengel observes that Ricoeur's entire philosophical project attempts to go beyond Merleau-Ponty's phenomenology of perception. The need to go beyond the limits of interiorized perception leads Ricoeur to search for explanations of perception that are less reliant on the intuitive, reproductive imagination of Merleau-Ponty's world of perception. The referent apple demonstrates the paradox of the non-referential referent, as the apple on the canvas "swells and bursts free from the confines of the wellbehaved draughtsmanship." Ricoeur explains this paradox in the context of fiction, affirming that: "Only when we start from the fiction, which seems to be non-referential in the sense that it has no object, that a new kind of reference may be opened thanks to the absence of a real referent, of an original. Whereas the reproductive image is marginal as regards reality, it's the function of productive imagination-of the fictional-to open and change reality. Productive imagination may enlarge and even produce new worldviews, new ways of looking at things. It may finally change even our way of being in the world" (Ricoeur 2009, 15: 4).

The image conceived as absence-as the submerged referent that has lost its proper weight-is surpassed by the image that has the capacity to change reality, to burst free from the confines of the work. Ricoeur terms this the iconic augmentation of reality. Borrowing from literary critic, François Dagognet, Ricoeur states that "through the image we may have an augmentation of reality and not merely a shadow within ourselves. To the extent that the image is not the copy of something exterior without an original, then it adds to reality" (Ricoeur 2009, 16: 4). Ricoeur does not conceive of a free-for-all augmentation of reality by every exteriorized thought any individual might have. Rather, he restricts his analysis of the productive imagination to techne, or work. A work is both an action (the work of painting or writing) and an object (a work of art/fiction). In either case, Ricoeur argues that work entails an intentional framing of the productive referent. In the case of the former, comparing painting to poetry, Ricoeur declares, "A painting must be a work or a frame while a poem is historically a kind of language game that has its own dimensions. Construing a hypothesis or a scientific model involves elaborating its project, its strategy for action in order to make a decision. There must 
always be some new project encompassing the production of imagination" (Ricoeur 2009, 15:6).

The bound work of poetic language and the development of odd predicates in the metaphoric statement exemplify the productive imagination's iconic augmentation of reality. For Ricoeur, the power and creativity of the productive imagination's iconic augmentation of reality is in the dialectic between the verbal and the visual. Seeing and image, Ricoeur suggests, are ingredients of perception encapsulated in the framework of perception. Or, as Ricoeur argues "[w]e can no longer oppose...imagining to seeing, if seeing is itself a way of imagining, interpreting, or thinking" (Ricoeur $2006,94)$. Ricoeur proposes a semantic model of the productive imagination where, in conjunction with a metaphoric use of language, the verbal and the visual are placed in a dialectical situation. "It's only when language is creative," Ricoeur affirms, "that imagination is creative" (Ricoeur 1974b, 110). Liberating imagination from the mind through a semantic approach releases the creative potential of the productive imagination. A modern theory of metaphor that stresses opening up a world creates new outlooks on the problem of the imagination. Or as Ricoeur pronounces, "We are prepared to inquire into the power of imagination, no longer as the faculty of deriving 'images' from sensory experiences, but as the capacity to let new worlds build our self-understanding. This power would not be conveyed by emerging images but by emerging meanings in our language. Imagination, then, should be treated as a dimension of language. In that way, a new link would appear between imagination and metaphor" (110).

The productive imagination is the "apperception of the sudden glimpse, of a new predicative pertinence, namely, a way of constructing pertinence in impertinence" (Ricoeur 1991, 173). A semantic model of productive imagination opens a horizon of hope where the possible is made probable. Kearney argues, "The metaphors, symbols, or narratives produced by imagination all provide us with 'imaginative variations' of the world, thereby offering us the freedom to conceive of the world in other ways and to undertake forms of action, which might lead to its transformation. Semantic innovation can thus point towards social transformation. The possible worlds of imagination can be made real by actions" (Kearney $2004 \mathrm{~b}, 42$ ). Using the parallels between the epistemological imagination and the poetic imagination, ${ }^{4}$ Ricoeur maintains, "there is a unity in the

4. The productive imagination's capacity to create and "disclose new dimensions of reality" is most acutely experienced in the fiction of narrative and poetry; however, as was the case with de-regionalizing hermeneutics, Ricoeur de-regionalizes the productive imagination by demarcating it into four domains; 1) the socio-cultural imagination, 2) the poetic imagination, 3) the epistemological imagination, 4) the religious 
functioning of thought in both poetic language and in science. There is not on the one hand science, which tells the truth, and on the other poetry, which expresses our emotions. The question of the unity of thought is at stake. If we can show that imagination is creative in the same way in models and in poetry, then we have a unifying view of the way in which thought in general is capable of novelty" (Ricoeur 2009, 19:1). To maintain this fundamental unity, a unity between the other domains must be demonstrable. Ricoeur demonstrates this unity by developing the parallelisms between the models of the epistemological imagination and the metaphoric process of the poetic imagination.

In Ricoeur's schema of the productive imagination, the model is to the epistemological imagination what the metaphor is to the poetic imagination and the parable is to the religious imagination. Each of the domains of the productive imagination shares a capacity for suspension and the projection of new possibilities to re-describe the world. For the social imagination, the concept of utopia is the Epoche that enables the projection of new possibilities. For the religious imagination, it is parabolization that suspends ordinary reference, enabling the projection of new possibilities. Parabolization is the metaphorization of text by the religious productive imagination through intertextuality. Ricoeur explains:

We may now approach by itself the phenomenon of parabolization through intertexuality that we have had to anticipate in order to account for the very dynamic of the narrative. I shall now take the two expressions "parabolization" and "metaphorization" as synonyms, it being understood that a metaphor can occur not only between words but between whole sequences of sentences. The isotopies play a role at this discursive level comparable to that of the semantic fields that enters into interaction in metaphor-sentences. Parabolization is the metaphorization of discourse. In the case of the narrative-parables, it consists of the metaphorization of a narrative taken as a whole. Intertexuality thus becomes an extension and consequently a particular interaction I have place at the center of my theory of metaphor. (Ricoeur 1995, 161)

This understanding of parabolization is important because it is the hermeneutic frame that guides the religious productive imagination.

The work of the productive imagination is most developed through Ricoeur's analysis of a modern theory of metaphor found in a number of his published and unpublished works, including the soon to be pub-

imagination. Each of these domains shares the capacity to use language to re-create reality imaginatively-that is, augment reality. What distinguishes these domains is the language code they use to augment reality. $(2009,16: 17)$. 
lished Imagination Lectures. ${ }^{5}$ In The Rule of Metaphor (2003) and in the earlier texts "Metaphor and the Main Problem with Hermeneutics" (1974b) and "Biblical Hermeneutics"(1975), Ricoeur develops the link between imagination and metaphor by reorienting the rhetorical theory of metaphor as substitution with an expanded understanding of metaphor in tension. A rhetorical theory of metaphor recognizes metaphors as figures of discourse concerned with naming, either by stylistic choice or to fill a lexical gap. Metaphors portray a divergence between the literal or proper sense of a word, and a figurative or improper sense of the word. The resemblance between the figurative and the literal functions as the grounds for substituting the figurative sense of a word by borrowing from the literal sense of word. Since we are operating at the level of words, the interpretation of metaphor is reduced to a semiotic interpretation, where the substitution of sense is not a semantic innovation at the level of the meaning of the sentence. Since there is no semantic innovation, metaphor gives no information about reality, and is therefore an ornamental addition to discourse, serving an emotive rather than rational function. These propositions, Ricoeur concludes, "are called into question by a modern semantic of metaphor" (Ricoeur 1975, 77).

A modern semantic theory of metaphor concerns itself with the semantics of the encompassing sentence before the semiotics of the word. Metaphor proceeds from a tension between two terms in a metaphoric statement. Ricoeur terms this tension a semantic impertinence, which is a phenomenon of predication at the level of the whole statement. The absurdity of a literal interpretation in the semantic context of the statement leads to the destruction of the literal, and a transformation of this sudden contradiction into a meaningful contradiction that makes sense (Ricoeur 1974b, 102). "Logical absurdity," Ricoeur explains,

5. George H. Taylor notes that these lectures are the central juncture where "Ricoeur is crystallizing his thoughts on poetics (and so fulfilling in a recast way the third part of his Philosophy of the Will). Imagination lies at the heart of his thinking at this time" $(2006,93)$. Corroborating Taylor's observation is Ricoeur's conclusion to his article "Metaphor and the Main Problem of Hermeneutics" (1974). Anticipating his work on the relationship between metaphor and imagination, Ricoeur concludes this article with the observation that a modern theory of metaphor that stresses opening up a world should also open up new vistas on the problem of the imagination. We are prepared to inquire into the power of imagination, no longer as the faculty of deriving "images" from sensory experiences, but as the capacity to let new worlds build our self-understanding. This power would not be conveyed by emerging images but by emerging meanings in our language. Imagination, then, should be treated as a dimension of language. In that way, a new link would appear between imagination and metaphor $(1974,110)$. 
create[s] a situation in which we have the choice between either preserving the literal sense of both the subject and the modifier and concluding to the meaninglessness of the whole sentence-or attributing a new meaning to the modifier such as the whole sentence makes sense... When I say, "man is a fox" (the fox has chased the wolf), I must shift from a literal to a metaphorical attribution if I want to save the sentence (102).

A modern theory of metaphor shifts the role of resemblance from substituting the figurative sense of a word by borrowing from the literal to the role of maintaining the tension between odd predicates where the distance (and therefore absurdity) between the literal interpretation is brought closer by the figurative interpretation. Rendering close what seems far resolves the semantic dissonance between two seemingly incompatible ideas. Far from being ornamental, metaphor, "consists rather in the reduction of the shock between two incompatible ideas, [and that] it is in this reduction of the shift, in this rapprochement, that we must look for the play of resemblance. What is at stake in a metaphorical statement is making a 'kinship' appear where ordinary vision perceives no mutual appropriateness at all" $(1975,78)$. This semantic innovation displaces a theory of metaphor as substitution or naming, with a theory of metaphor in tension between odd predicates:

In metaphor, the tension between the words and especially the tension between two interpretations, one literal and one metaphorical, in the whole sentence gives rise to a veritable creation of meaning of which rhetoric perceived only the end result. In a theory of tension, which I am here opposing to a theory of substitution, a new signification emerges that deals with the whole statement. In this respect, metaphor is an instantaneous creation, a semantic innovation which has no status in established language and which exists only in the attribution of unusual predicates. In this way, metaphor is closer to the active resolution of an enigma than to simple association by resemblance. It is the resolution of a semantic dissonance. (79)

Substitution metaphors easily shift between literal and figurative meaning, but tension metaphors create new meaning precluding the restoration of the proper meaning of the odd predicates. Ricoeur concludes that the productive imagination plays a role in the transition from literal incongruence to metaphoric congruence. We must forget the mechanical model of balls hitting one another, as in the Newtonian model of the association of ideas. It is not at all an association by resemblance. There is no parallelism between similarity and contiguity. Instead, we try to derive likeness from the functioning of an odd predicate and derive imagination from likeness." Based on a semantic theory of metaphor, "Imagination has 
to be linked to the role of likeness in the production of a new meaning, a new sentential meaning, a new predicative meaning (Ricoeur 2009, 16: 8).

This modern semantic theory of metaphor leads Ricoeur to a metaphoric concept of truth. A metaphoric concept of truth, Ricoeur maintains, recognizes that the poetic function and the rhetorical function "cannot be fully distinguished until the conjunction between fiction and re-description is brought to light" (Ricoeur 2003, 291). The rhetorical function is the inverse of the poetic function; it only contributes ornamentation to discourse, adding nothing new to the generation of meaning. Conversely, it is the function of the poetic to seek and "re-describe reality by the roundabout route of heuristic fiction" (291). This indirect route is undertaken by metaphor, which Ricoeur describes as "that strategy of discourse by which language divests itself of its function of direct description in order to reach the mythic level where its function of discovery is set free" (Ricoeur 2003, 247). Ricoeur concludes that a metaphoric concept of truth is inescapably paradoxical:

The paradox consists in the fact there is no other way to do justice to the notion of metaphorical truth than to include the critical incision of the (literal) "is not" within the ontological vehemence of the (metaphorical) "is." In doing so, the thesis merely draws the most extreme consequence of the theory of tension. In the same way that logical distance is preserved in metaphorical proximity, and in the same way as the impossible literal interpretation is not simply abolished by the metaphorical interpretation but submits to it while resisting, so the ontological affirmation obeys the principle of tension and the law of "stereoscopic vision." It is this tensional constitution of the verb "to be" that receives its grammatical mark in the "to be like" of metaphor elaborated into simile, at the same time as the tension between same and other is marked in the relational copula. (302)

Undergirding this understanding of metaphoric truth is a conception of the productive imagination's capacity to re-imagine reality by critically and imaginatively inserting the literal is not within the ontological vehemence of the metaphorical is. Or, as Ricoeur writes, "The question then is whether the iconic moment of metaphor stands outside every semantic approach, and whether it is not possible to account for it starting from the paradoxical structure of resemblance. Would not the imagination have something to do with the conflict between identity and difference?" (235). Metaphorization/Parabolization is the iconic moment of metaphor that stands outside every semantic approach transcending the text through the metaphoric transfer from text to life. The incongruence of the metaphoric statement is resolved when the world in front of the text is transformed from a proposed utopia to a probable world. Rastafari 
hermeneutic of word, sound and power is an example par excellence of the how the world in front of the text and behind the text is transformed, that is parabolized, through the metaphoric transfer from text to life.

\section{Rastafari excursus}

While the verbal and visual features of Rastafari are studied, less attention has been given to the hermeneutics of Rastafari discourse. The Rastafari chant of word, sound and power completes the metaphoric process where life encounters text and feelings, "are 'attuned to' aspects of reality which cannot be expressed in terms of the objects referred to in ordinary language" (Ricoeur 1978, 158). Rastafari scholar, Barry Chevannes' describes word, sound and power as a trinity:

It is sound not only because its effect is aural but also because it is capable of quality, capable of being "sweet," of thrilling the hearer. It is power because it can inspire responses such as fear or anger or submission. The articulateness, tonal variation, pitch, and formalism are the Rastafari version of the sweetness of the sermons in lower-class churches, and to describe this level of expression they use the word "to chant." (1994, 227)

Ricoeur's hermeneutic of the religious productive imagination provides an important link between the verbal and the visual features of Rastafari discourse and the theological and metaphoric reasoning of Rastafari hermeneutics.

As previously noted, the power and creativity of the productive imagination is housed in the dialectic between the verbal and the visual. Ricoeur rejects the traditional reproductive model of image, proposing a semantic model of the productive imagination, where in conjunction with a metaphoric use of language, verbal and visual are placed in a dialectical situation. He argues, "It's only when language is creative that imagination is creative... Imagination, then, should be treated as a dimension of language. In that way, a new link would appear between imagination and metaphor. Here is where we pass from the work of the imagination in the text to the world of imagination about the text" (Ricoeur 1974b, 110). Ricoeur identifies three movements in this transfer. The first movement, thinking, produces new types of assimilations between the nearness and farness of the metaphoric statement by "seeing" similarities. The second movement, seeing, incorporates the pictorial element while avoiding a weakened sensorial model of image. Seeing introduces the formula for the constructions of icons controlled by semantics, which is "the way in which depiction occurs in predicative assimilation: something appears on which we read the new connection" (150). 
The third movement, Epochě of sense, creates an Epochě where the literal and descriptive sense and reference of language is suspended by the metaphorical sense and reference of the odd predicate. Ricoeur appropriates the term Epochě in the literary sense, as "the moment of negativity brought by the image in the metaphoric process" (Ricoeur 1978, 151). The negation Ricoeur indicates as the moment of negativity is not the place of the transcendental subject, as with Husserl, or the parasitic image he has thus far denounced; rather, it is the negation that "appears because the image places the sense in the dimension of suspension, of Epochě, of fiction" (Ricoeur 1978, 151). Epochě returns Ricoeur to a basic understanding of meaning in the relationship between sense and reference in a metaphorical expression.

Ricoeur's semantic theory of metaphor inverts the traditional relation between sense and reference in poetic language that interiorizes meaning. Ricoeur takes the expression "split reference" "as our lead in our discussion of the referential function of metaphoric statement. This expression, as well as the wonderful 'it was and it was not' contains in nuce all that can be said about metaphorical reference" (Ricoeur 1978, 153). The term "split reference" denotes the capacity for poetic reference to make communication ambiguous, rather than negating the referential function. Ricoeur extends this characteristic of metaphoric sense emerging from the negation of the literal sense to ordinary descriptive language arguing that,

The suspension of the reference proper to ordinary descriptive language is the negative condition for the emergence of a more radical way of looking at things, whether it is akin or not to the unconcealing of that layer of reality which phenomenology calls preobjective and which according to Heidegger, constitutes the horizon of all our modes of dwelling in the world... In the same way as the metaphorical sense not only abolishes but preserves the literal sense, the metaphorical reference maintains the ordinary vision in tension with the new one... (154)

This first movement in the metaphoric transfer from the work of the imagination in the text to the world of imagination about the text-thinking-is illustrated by the reasoning of Rastafari elder Mortimo Planno in the text, Rastafarian the World's Most Strangest Man. Planno writes, "A Text is taken to draw a conclusion which can be counted upon as a test. I an I take up a Bible and opened it. So I an I began in Genesis I. Question asked who spoke? Answer given God spoke! Understand! Words are life!! I an I accept the word is God! Here. but where will we go from here?" (Planno 2006, 12).

The phrase, "Question asked who spoke? Answer given God spoke! Words are life!!” illustrates the imagination's production of new types of 
assimilations between the nearness and farness of the metaphoric statement by "seeing" similarities. In this case, Planno begins with the act of reading, as he takes up a text. This act prompts the question, "Question asked who spoke? Answer given God spoke! Words are life." The words of the text are read by Planno, but the question asked in the text is: "who spoke?" The proclamation of the text is linked to the manifestation of creation: "God spoke!" in the declaration "Words are life!! I an I accept the word is God." Thinking "sees" the assimilation between word as text, word as sound and word as power. Planno does not stop here, but looks beyond the text, writing, "God created all these beautiful things, it appear that God had eyes to see so he looked around and said come let us create man and man was created, both male and female. I an I accept that God is the word the word made into flesh and God become a man and finish creation as a man" (12).

The second movement in the metaphoric transfer from the work of the imagination in the text to the world of imagination about the text-seeing-is illustrated by the phrases "eye to see," "appear," "look around," and "I and I." Ricoeur identifies seeing as the schematization of iconic presentations. He argues that,

By displaying a flow of images, discourse initiates changes of logical distance, generates rapprochement. Imaging or imagining, thus, is the concrete milieu in which and through which we see similarities. To imagine, then, is not to have a mental picture of something but to display relations in a depicting mode. Whether this depiction concerns unsaid and unheard similarities or refers to qualities, structures, localizations, situations, attitudes, or feelings, each time the new intended connection is grasped as what the icon describes or depicts. (Ricoeur 1978, 150)

The iconic presentation that is schematized is the concrete milieu of creation through which Planno sees the similarities in God speaking creation and sharing in that creation through the incarnation of the word made flesh. Or, as Planno writes, "I an I accept that God is the word the word made into flesh and God become a man and finish creation as a man. So he God created I an I in his own image and likeness" (Planno 2006, 13). I an I is the odd predicate of the metaphoric statement that represents the transfer and divinization of the self through unity with God.

The importance of sight to Rastafari is illustrated by Planno's use of the trope of vision in his description of the manifestation of the word of God, spoken in creation: "It appear that God had eyes to see so he looked around and said come let us create man and man was created, Both male and female. I an I accept that God is the word made into flesh and God become a man and fin- 
ish creation as a man" (Planno 2006, 13). The iconic representation is schematized as creation and recognizes the similarities between the words speaking, seeing and creating.

Planno's assertion that "I an I accept that God is the word the word made flesh and God become a man to finish creation as a man," is an affirmation of a new type of assimilation between the nearness and farness of the metaphoric statement by seeing similarities between God and humanity. Seeing similarities, Ricoeur argues, "Is homogenous to discourse itself, which effects the logical discourse, the rapprochement itself. The place of and role of the productive imagination is there in the insight, to which Aristotle allude when he said that to make good metaphors is to contemplate likeness-theorein to omoion" (Ricoeur 1978, 147). The third movement in the metaphoric transfer from the work of the imagination in the text to the world of imagination about the text-Epoche of sense-is illustrated by the use of I-talk in Rastafari discourse. I-talk is a primary example of an odd predicate that Rastafari uses to re-imagine and re-create, through language, the world. The semantics of I-talk sees the incarnation of the word as a split-reference, between the first person singular, the third person plural, and the incarnation of God therefore signifying the divine principle (Edmonds 1998, 33). I an I represents the unity between the individual "I," and the divine "I" and through this unity, the unity between two or more individuals expressed as I an I. I an I is used as a subject even when it references an object "to indicate that all people are active, creative agents and not passive objects" (33).

The Rastafari term, citing-up, is a useful metaphoric statement that captures the essence of Rastafari's hermeneutic of word, sound and power. If one can get past Murrell and William's essentialization of Rastafari, their description is instructive:

Essentially, Rastas have adopted an Africa-centered and free-style reading of biblical materials; but they are not united on matters of biblical interpretation, and except for the practice of citing-up the Bible, they have not defined or developed a consistent methodology for interpreting biblical texts. The art of citing-up places less emphasis on syntax, context, and literary genre of the text and more on the speaker, the setting, and the scene. (Murrell and Williams 1998, 328)

Murrell and Williams insistence on a consistent method blinds these exegetes to the underlying hermeneutic implicit in Rastafari's approach to the Bible. Despite this short-coming, Murrell and Williams provide a good description of the reasoning of "citing-up": "Citing-up involves a combination of proof text, running oral and written commentaries (in 
somewhat of a rabbinic style) associations of traditional myths and stories with contemporary parallels, double-intentional (i.e., having double layers of meaning) symbols, and very loose, free-style interpretations of biblical materials" (328). Citing-up is what Ricoeur identifies as the phenomenon of parabolization through intertextuality. Metaphorically, citing refers to the citing of biblical narratives and to the sighting of the metaphoric truth between the text and the context. Additionally, citingup refers to the re-citing of the word of God in praise to Jah Rastafari, and the sighting of Jah Rastafari in the text and context of the ritualized action of word, sound and power. Through citing-up, Rastafaris gain insights into their lived experience in exile and the promise held out in the recognition of their divinization through the indwelling of Jah, Rastafari. In short, Rastafari hermeneutic of word, sound and power begins with embedded experience that finds meaning in context mediated through language.

Rastafari word, sound and power is a consistent hermeneutic method of "parabolization that consists of metaphorization of a narrative taken as a whole" (Ricoeur 1995, 161). The ritual drama of Rastafari reasoning is an embodiment of odd predication that brings near what is far, and in making sense of the historical, social, political, and economic context of slavery, colonialism, racism, and oppression interpreted through the lens of Biblical text, imagines the truth while projecting hope. The movement between the figurative and the literal, past and current, personalities and events in scripture, and personalities and events in the world today, are all inventions of the free discourse of metaphor (Murrell and Williams 1998, 328). Viewed this way, word, sound and power is a hermeneutic that parabolizes the narrative of slavery and continued racial and economic oppression in Babylon, while projecting hope in liberation through repatriation to Zion.

\section{Conclusion}

We began this essay with the Ricoeur's assertion that "We have at our disposal a symbolic logic, an exegetical science, an anthropology, and a psychoanalysis, and perhaps for the first time, we are able to encompass in a single question the problem of the unification of human discourse" (Ricoeur 1977, 3). What is at our disposal is a hermeneutic that is indebted to past interpretation, is in dialogue with present conversations, and remains open to future innovation. A postmodern turn to Ricoeur's hermeneutic of the productive imagination provides a methodological orientation that creatively frames our investigations, while paradoxically remaining open to new possibilities, as illustrated by Rastafari's herme-

\section{equinoxonline}


neutic of word, sound and power. Rastafari enlarges our hermeneutic horizon as it enriches our understanding of text and textuality. Word, sound and power is a hermeneutic that chants the truth of being and hope: being in Babylon, hoping for Zion.

Rastafari, like Fanon, refuses to accept historically contingent narratives of race and slavery as necessary universal truths. Rastafari's hermeneutic of word, sound and power is a witness to hope that in naming God recognizes God's liberating acts and anticipates the liberation of all people. It is through I an I that Ricoeur's ontological bearing of feelings is joined. Feelings, Ricoeur argues, "have ontological bearing, that they are ways of 'being-there' of 'finding' ourselves within the world...because of feelings we are 'attuned to' aspects of reality which cannot be expressed in terms of the objects referred to in ordinary language" (Ricoeur 1978, 158). This I an I ontological bearing, their being-there, conceptually framed by the religious productive imagination recognizes the world of alienating distanciation as Babylon and Zion as the Epochě of hope out of and from which liberation is projected. In so doing, Rastafari embodies the iconic moment of parabolization that stands outside every semantic approach.

Being attuned to these feelings has the potential to shift, for those who have eyes to see, our gaze beyond the ordinary canons of sacred texts to appreciate the erstwhile neglected intertextuality of the canon within the canon, which is the truth, the word made flesh, written on the other half of the heart. This metaphoric transfer provides a methodology whereby hermeneutics can bridge traditional boundaries, bringing different disciplinary tools to the process of analysis, while opening up a sustained dialogue between and among scholars and others who are interested in religion, textuality, media, and mediation in the contemporary world

\section{References}

Castelli, Elizabeth A. 2004. "The Ekklesia of Women And/as Utopian Space: Locating the Work of Elizabeth Schüssler Fiorenza in Feminist Utopian Thought." In On the Cutting Edge: The Study of Women in Biblical Worlds: Essays in Honor of Elisabeth Schüssler Fiorenza, edited by Jane Schaberg, Alice Bach, and Esther Fuchs, 36-52. New York: Contiuum.

. n.d. "Postscripts: The Journal of Sacred Texts and Contemporary Worlds". Journal Portal. http://www.equinoxjournals.com/POST/index.

Chevannes, Barry. 1994. Rastafari: Roots and Ideology. Syracuse, NY: Syracuse University Press.

Davison, Phil. 2006. "Mortimo Planno." The Guardian, March 23, sec. World news. http://www.guardian.co.uk/news/2006/mar/23/guardianobituaries.religion. Accessed September 10, 2013. 
Dussel, Enrique D., and Eduardo Mendieta. 1999. The Underside of Modernity: Apel, Ricoeur, Rorty, Taylor, and the Philosophy of Liberation. Amherst, NY: Humanity Books.

Edmonds, Ennis B. 1998. "The Structure and Ethos of Rastafari." In Chanting Down Babylon: The Rastafari Reader, edited by Nathaniel S. Murrell, William David Spencer, and Adrian Anthony McFarlane, 349-360. Philadelphia, PA: Temple University Press.

Fanon, Frantz. 1965. The Wretched of the Earth. Translated by Richard Philcox. New York: Grove Press.

.1967. Black Skin, White Masks. Translated by Constance Farrington. New York: Grove Press.

Gadamer, Hans-Georg. 2004. Truth and Method. 2nd, rev. ed. Translated by Joel Weinsheimer and Donald G. Marshall. New York: Continuum.

Kearney, Richard. 2004a. Debates in Continental Philosophy. New York: Fordham University Press. http://dx.doi.org/10.5422/fso/9780823223176.001.0001 .2004b. On Paul Ricoeur: The Owl of Minerva. Burlington, VT: Ashgate.

Merleau-Ponty, Maurice. 2007. The Merleau-Ponty Reader. Edited by Ted Toadvine and Leonard Lawlor. Evanston, IL: Northwestern University Press.

Moltmann, Jürgen. 2000. Experiences in Theology: Ways and Forms of Christian Theology. Minneapolis, MN: Fortress Press.

Murrell, Nathaniel and Burchell K. Taylor. 1998. "The Black Biblical Hermeneutics of Rastafari." In Chanting down Babylon: The Rastafari Reader, edited by Nathaniel Samuel Murrell, William David Spencer, and Adrian Anthony McFarlane, 326-349. Philadelphia, PA: Temple University Press.

Nielsen, Cynthia R. 2011. "Resistance Through Re-Narration: Fanon on De-Constructing Racialized Subjectivities." African Identities 9: 363-385. http://dx.doi.org/10.1080/14725843.2011.614410

Planno, Mortimo. 2006. The Earth Most Strangest Man. New York: Comitas Institute for Anthropological Study. www.cifas.us/material/earth-most-strangestman. Accessed September 10, 2013.

Ricoeur, Paul. 1974a. The Conflict of Interpretations. Evanston, IL: Northwestern University Press.

. 1974b. "Metaphor and the Main Problem of Hermeneutics." New Literary History 6: 95-110.

. 1975. "Biblical Hermeneutics." Semeia 4: 29-148.

1977. Freud and Philosophy: An Essay on Interpretation. Translated by Denis Savage. New Haven, CT: Yale University Press.

. 1978. "The Metaphorical Process as Cognition, Imagination, and Feeling." Critical Inquiry 5: 143-159. http://dx.doi.org/10.1086/447977

- 1981. Hermeneutics and the Human Sciences: Essays on Language, Action, and Interpretation. Translated by John B Thompson. Cambridge: Cambridge University Press.

. 1984. Time and Narrative. Vol. 1. 3 vols. Chicago, IL: University of Chicago Press. http://dx.doi.org/10.7208/chicago/9780226713519.001.0001 
1988. Time and Narrative. Vol. 2.3 vols. Chicago, IL: University of Chicago Press. http://dx.doi.org/10.7208/chicago/9780226713533.001.0001

1991. From Text to Action. Evanston, IL: Northwestern University Press. 1995. Figuring the Sacred: Religion, Narrative, and Imagination. Minneapolis, MN: Fortress Press.

. 2003. The Rule of Metaphor. London: Routledge \& Kegan Paul. . 2006. On Translation. New York: Routledge.

. 2009. Imagination Lectures: Chicago, 1975. Edited by George Taylor. Pittsburgh, PA: unpublished manuscript.

Stiver, Dan. 2001. Theology After Ricoeur: New Directions in Hermeneutical Theology. Louisville, KY: Westminster John Knox Press.

Taylor, George H. 2006. "Ricoeur's Philosophy of Imagination." Journal of French Philosophy 16: 93.

Van den Hengel,John. 2010. "Practical Theology and the Emergence of New Self." Unpublished manuscript.

Westphal, Merold. 2001. Overcoming Onto-Theology Toward a Postmodern Christian Faith. Bronx, NY: Fordham University Press. http://dx.doi.org/10.5422/ fso/9780823221301.001.0001 